\title{
FEATURES OF THE MUSIC-EDUCATIONAL LIFE OF THE WESTERN UKRAINIAN LANDS (ON THE EXAMPLE OF STANISLAVIV OF THE END OF THE XIX - THE FIRST THIRD OF THE XX CENTURIES)
}

\author{
Romaniuk L. B.
}

\section{INTRODUCTION}

An important component of the history of any country is the history of its culture. Nowadays, when Ukrainian people search for their national identity and values, there is a need for a comprehensive study in the field of national spiritual heritage. The study and scientific understanding is required not only concerning the artistic processes taking place throughout Ukraine, but also those artistic phenomena that have left a noticeable mark at the regional level.

The second half of the 19 th - first half of the $20^{\text {th }}$ century became a period of intensive development of cultural and artistic life in Western Ukrainian lands, characterized by the transformation of individual cities into powerful centers of culture with their own infrastructure and traditions acquired during the centuries. The process of formation and development of culture and art in Stanislaviv (now Ivano-Frankivsk) has a number of immanent features and can be characterized by a tendency to assimilate regional, national and European cultural achievements.

The change of values associated with the "spring of nations" in 1848 in Europe was echoed in Western Ukraine, and led to the development of the liberal-democratic movement, progressive literary movements, the "Russian Trinity" standing at their origins. The national revival took place in various ways - from the renewal of artistic, cultural and educational thought to the creation of political parties and organizations. Just like in other cities of Western Ukraine, a district Russian Council was organized in Stanislaviv, and later a number of Ukrainian, Polish, German, Jewish political parties, populist and Muscovite groups, and a number of economic institutions were established. Despite the complexity of the historical and political situation of the second half of the $19^{\text {th }}$ - first third of the $20^{\text {th }}$ century, there was a spiritual upsurge, which resulted in a progressive breakthrough in various spheres of culture, with artistic and educational life as an important subsystem of it.

Problems of formation and development of music and arts education and upbringing in the western parts of Ukraine have been repeatedly considered by domestic scholars, but the coverage of situation in some cities (including Stanislaviv) is quite poor, which is none the less important since it helps to recreate the complete picture of the situation in the region. An important place 
in the process of scientific research is occupied by historical and culturological works of modern domestic scientists V. Hrabovetsky, M. Kuhutyak, V. Burdulanyuk, B. Havriliv, P. Arsenych, H. Bilavych and B. Savchuk, who review the activities of Ukrainian societies Prosvita (Enlightment), Ridna Shkola (Native School), Soyuz Ukrainok (The Union of Ukrainian Women), Ruska Besida (Russian Conversation), Stanislavivsky Boyan and others, emphasizing their importance in the organization of cultural and artistic life of Galicia. However, in the context of their role in the formation of music education in Stanislaviv and its environs, the activities of these formations are covered only in fragments. What concerns the educational practice of Polish and Jewish societies - there is almost no information. Also as a necessary and essential part of historiography on the topic of scientific research we consider special works of Ukrainian musicologists, in which various aspects of the musical culture of Prykarpattia and partly Stanislaviv (M. Zahaykevych, L. Kiyanovska, Y. Bulka, L. Mazepa, etc.) were the subject of study. L. Mazepa addressed the history of music education in Eastern Galicia, he researched this sphere of human activity in Lviv, as well as opened some pages of its development in other cities, including Stanislaviv. However, it's the first time that an integral and comprehensive examination of the panorama of Stanislaviv's musical and educational life is being carried out.

\section{Activities of public societies and educational institutions of Stanislaviv in the cultural and educational sphere}

Developing its activities in accordance with current trends of the period and relying on legal principles, the Stanislaviv community managed to create an extensive network of artistic, economic and political organizations in the city and region, the aim of which was providing the spiritual and economic needs of the society. Stanislaviv was one of the first cities in Galicia to be actively involved in the latest cultural processes, reflected in the founding of a number of public and educational organizations, devoting a big part of their work to music. Prosvita became a society whose work was especially important and multifaceted. It played the role of an extensive socio-political institution, the mother of numerous cultural and economic societies, such as Ridna Shkola (Native School), Sich, Sokil, The Union of Ukrainian Women, Farmer and others ${ }^{1}$. In the seventies of the $19^{\text {th }}$ century the activities of Prosvita spread to Stanislaviv Voivodeship. The wide range of tasks facing this society included the establishment of choirs, orchestras, amateur theater groups; training of conductors for clubs; opening of educational courses for directors and conductors; arranging drama performances and concerts; organization of

\footnotetext{
${ }^{1}$ Залеський О. Музичне життя Станислава. Альманах Станиславівської землі. Збірник матеріалів до історії Станиславова і Станиславівщини. Т. І. Нью-Йорк - Торонто - Мюнхен, 1985. С. 555. 
drama groups and choirs contests; opening the libraries with music and drama literature. Simultaneously with Prosvita, the Ukrainian, Polish, Jewish and German societies Ruska Besida (Russian Conversation), Ridna Shkola (Native School), Soyuz Ukrainok (The Union of Ukrainian Women), Kamenyari, Frogsin, Gaskala and others became active in the field of music education and upbringing, organizational, educational and advocacy work, resulting in innovative initiatives and intensive progress in the network of private schools and preschools, in which the aesthetic education of youth took an important place. An important component of educational activities of cultural and public organizations was the introduction of various courses (conductors, directors), seminars and clubs on various subjects, as well as the organization of art contests, helping to improve the performance of amateur choirs and drama groups ${ }^{2}$. Taking care of the Ukrainians' level of education, Prosvita organized Educational Courses, the program of which included theoretical and practical parts. The theoretical course included lectures, and the practical course offered acquaintance with various forms and methods of extracurricular education, which included various aspects of spiritual, social (clubs, public holidays), aesthetic and moral education (performances, choirs and orchestras, exhibitions). The activities of the courses helped to solve the problem of experienced and qualified personnel shortage making it hard to organize work in various fields of culture ${ }^{3}$.

The public society Ridna Shkola (Native School), which in 1901 took over the pedagogical and school tasks from the "mother of Ukrainian schooling" the Prosvita society, started a broad network of educational institutions in Stanislaviv. It included preschools, folk and vocational schools, gymnasiums, teachers' seminaries, giving art of music one of the leading places in their system of education and upbringing ${ }^{4}$. Alongside with singing, music lessons and playing musical instruments, which occupied an important place in the curricula of the Society's schools, lectures, concerts, debates, conversations were widely practiced, contributing to the deepening and generalization of knowledge. Optional classes and subject groups were the pedagogically justified forms of teaching and education. These included: courses in song, dance, music, etc ${ }^{5}$. An important educational innovation, introduced into the curricula of secondary schools of the Society in 1936 were "Music auditions", the programs of which were compiled in cooperation with the Higher Music

\footnotetext{
2 Звіт про проведення режисерських курсів керівників сільських аматорських гуртків. Відношення про проведення Свята Молоді. ДАІФО (Державний архів Івано-Франківської області). Ф. 378. оп. 1. спр. 46. 13 арк.

Загайкевич М. Музичне життя Західної України другої половини ХІХ століття. М. Загайкевич. Київ : АН УРСР, 1960. 191 с.

4 Загайкевич М. Музичне життя Західної України другої половини ХІХ століття. М. Загайкевич. Київ : АН УРСР, 1960. 191 с.

5 Звідомлення управи приватної дівочої гімназії кружка «Рідної школи» в Станиславові за шкільні роки 1920/21 - 1926/27. ДАІФО (Державний архів Івано-Франківської області). Станиславів, 1927. $30 \mathrm{c}$.
} 
Institute in Lviv. They were designed to allow one to choose the topics that were most relevant and interesting for each institution. The method of organizing music auditions included theoretical and practical parts. In order to achieve the most conscious and thoughtful perception of music before its performance, students were offered a summary with concise information about the selected piece of music. Themes of musical auditions are divided into nine sections, which in their turn are systematized into two parts: "A" auditions dedicated to the work of one composer; "B" - auditions dedicated to the study of dance music history. These and other forms of education and upbringing significantly increased the efficiency of the educational process and gave an opportunity to develop creative thinking of young students. In order to spread advanced educational ideas among the general population of Galicia periodical pedagogical press was being published under the auspices of the Pedagogical Society: magazines Home and School, Ray, Our School, Ukrainian Teacher, Teacher's Word, as well as textbooks in Ukrainian' ${ }^{6}$.

At the turn of the nineteenth and twentieth centuries, music education in Western Ukraine functioned in organizations and institutions of various levels and profiles and was implemented in certain forms. These included: 1. unorganized forms: a) lower (private and home); b) cultural and educational organizations (public, educational and musical societies); 2. organized forms of music education: a) specialized music institutions, divided into lower, middle and higher levels); b) general and specialized institutions of different levels and profiles (gymnasiums, schools, vocational schools, seminaries, etc.). Organized forms of music education arose as a result of intensive development of unorganized forms of music education in cooperation with the intensification of musical life of the city and the region and were implemented in specialized educational institutions. Many lower-level educational institutions were single-profiled (singing schools, playing certain instruments - piano, violin, zither), had a small number of teachers and students. Secondary and higher music schools, starting from the $19^{\text {th }}$ century, played the role of the main musical culture centers in cities and regions and were engaged in a wide range of educational and upbringing activities, they trained qualified professionals. Music and educational institutions used their statutes, individualized curriculum, which determined the number of years of study (from 5 to 12), list of subjects, forms of control. In addition to musical educational schools, which were a priority, there were schools of drama art, plasticity, rhythmics and artistic dance. Thus, significant changes in the field of music in Stanislaviv in the period under study were determined by the intensive formation of the system of music education, which was reflected in the activities of educational institutions of different types and levels.

\footnotetext{
${ }^{6}$ Білавич Г., Савчук Б. Товариство «Рідна школа» (1881-1939 рр.). Івано-Франківськ : Лілея - НВ, 1999. $205 \mathrm{c}$.
} 
Music and art education was an important and necessary part of the activities in the system of education of secondary and specialized educational institutions of Stanislaviv. Despite the influence of some negative factors that inhibited the process of dynamic growth and, consequently, progress in this area, in the late nineteenth - first third of the twentieth century the level of wide circles' interest in music education and awareness of its necessity has significantly increased.

Since the 1880's, a network of church singing schools had been founded in Galicia, the activities of which have made a significant contribution to the development of music education and upbringing. One of the first schools of this type was founded in Stanislaviv in October 1888 by the deacon and regent of the cathedral choir Ignatii Polotniuk. The curriculum of this educational institution included the following subjects: Religion, Grammar, Irmologion, Church Echoes, Holiday Songs, Church Charter, Liturgics, Church Dictionary, Damascene Hand, Arithmetic, Music Theory and Choral Singing ${ }^{7}$. The opening of the church singing school in Stanislaviv (later - a lower theological school (bursa) for deacons) was an important step in raising the level of music education and culture of the city and the region. It is the clergy to whom Galicia in general owed the formation and development of musical art, because the church was the basis of education, it was from it that the Galician musical revival originated.

Alongside with theological educational institutions, the teaching of music, singing and musical instruments playing was included in the secular public and private secondary schools' curricula, including public (primary) schools, gymnasiums and seminaries.

Gymnasiums were not only powerful research centers with qualified teaching staff, logically built education systems, large libraries and strong material base, but also served as educational centers with a developed system of student government, and the priority of national spiritual self-affirmation. These institutions used various methods of developing creative abilities and raising the level of their students' culture. These tasks were implemented through the provision of appropriate education, which was due to the presence of music and singing in the curriculum, as well as drawing and dance, and involving students in the activities of artistic and educational organizations, engaging them in preparing various art events by their own groups. "Scientific clubs" and their divisions were the centers of cultural and educational activities of gymnasiums ${ }^{8}$. Schoolchildren prepared public speeches with scientific reports, concerts and drama performances for the cultural and social environment of Stanislaviv. The upbringing of an educated, gifted and nationally conscious person with a rich spiritual world and proactive life

\footnotetext{
7 Діло. Львів, 1889. Ч. 207.

8 Звіт дирекції державної гімназії з руською викладною мовою у Станиславові за шкільний 1936/37. Станиславів, 1937. 47 с.
} 
position was the main goal of educational institutions of this type. Although singing as a subject in Stanislaviv's educational institutions, as elsewhere in Galicia, was on an equal footing with other school subjects, Ukrainian educational institutions lagged far behind German and Polish ones in this respect. The main reason was the reluctance of qualified music teachers to work in primary schools, lacking both appropriate textbooks and methods of teaching singing ${ }^{9}$.

In the early twentieth century Stanislaviv's educational institutions used V. Matyuk's textbook "Russian Songbook of Folk Schools" (part 1), d'Arma Dietz, recommended by the ministry and the regional school council. In its theoretical part, it was quite comprehensive, but the exercises (for one, two, three voices) were based solely on Polish song material. For Ukrainians, there was also I. Kyprian's "Textbook of Primary Information and Singing”, but it was limited to the theoretical part, without providing information about the voice, its range, registers, and elementary vocals. Later, in 1925, F. Kolessa's "School Singer in 2 Volumes" appeared. In 1927, M. Kutsia's textbook "The Science of Solfeggio" was published in Stanislaviv, based on melodies with lyrics ${ }^{10}$.

Alongside with other educational institutions, Stanislaviv's teachers' seminaries had an active cultural and artistic life. As well as other disciplines in the curriculum, music, singing and playing musical instruments (piano and violin) took an important place. At the end of each school year, there were summary concerts, involving the best students. Choirs, orchestras, vocal and violin ensembles (duets, trios, quartets) were formed among the seminarians.

A significant part of gifted children, in tandem with their studies at the female seminary, improved their level of performance in Stanislaviv's specialized music institutions, and were also participants in amateur cultural events, artistic societies and creative groups, which contributed to the enforcement of these institutions' and organizations' role in the revival of the city's musical life ${ }^{11}$.

Thus, music education was an important and necessary part of the education system of secondary and specialized educational institutions' activities. At the end of the 19th and the first third of the 20th centuries the interest in music education and awareness of the music art's and education's importance had significantly increased among Stanislaviv's general public. Without a certain quantity of trained personnel, it was impossible to create and effectively operate high-level music societies and educational institutions,

\footnotetext{
9 Людкевич С. П. Дослідження, статті, рецензії, виступи : в 2-х томах / С. П. Людкевич / упорядкування, редакція, переклади, вступна стаття і примітки 3. Штундер. Львів : видавництво М. Коць; НАНУ, Інститут українознавства ім. І. Крип'якевича, 2000. 815 с. (Серія: Історія української музики, вип. 5 ; т. 2.)

${ }^{10}$ Куцій М. Наука сольфежа основана на мельодіях з текстом : Підручник для молодіжи. Перша частина. Станиславів, $1927.54 \mathrm{c}$.

${ }^{11}$ Станіславська приватна жіноча учительська семінарія Сестер Василіянок. ДАІФО (Державний архів Івано-Франківської області). Ф. 548. оп. 1, спр. 5. 49 арк.
} 
and, consequently, a fully-fledged development of musical life was impossible either.

\section{Professional music and educational training in the branch of the Higher Music Institute named after Mykola Lysenko}

The characteristic trend in the system of education and upbringing of the late nineteenth - first half of the twentieth century was a combination of the learning process in primary schools, gymnasiums and seminaries with education in specialized music schools, which had been caused by historical objectivity.

The active work of D. Sichynsky and E. Yakubovych led to the opening of one of the first Ukrainian music schools of a new type in the choral society Stanislavivsky Boyan in Western Ukraine (1902). This marked a new page in the history of cultural struggle for national education. According to the performers' level of training, this music school could be attributed to multidisciplinary educational institutions of the lower type. The curricula of the first year of its activity provided division into three departments of piano, stringed instruments (violin, viola, cello, double bass, zither), solo and choral singing, and since 1904-1905 also a department of wind instruments was established $^{12}$. The scope of subjects included, in addition to the specialty, as mandatory for all the departments such theoretical disciplines: elementary music theory, harmony, counterpoint, composition, instrumentation, history and aesthetics of music. The most talented graduates of the music school had the opportunity to continue their education in secondary and higher educational institutions, the others received certificates giving the right to teach in secondary and music educational institutions of lower level ${ }^{13}$.

With the development of the idea of understanding music as a science in the education system, the music school was being reorganized into a branch of the Lviv Higher Music Institute named after M. Lysenko, who played a leading role in the formation and development of the national music school in the Stanislaviv region, contributed to the emergence of a whole galaxy of talented and trained musicians who had been forced to be satisfied with amateur level or acquire knowledge in art institutions abroad before the emergence of this school ${ }^{14}$.

Osyp Zaleski, a well-known public figure, musicologist, composer and teacher, contributed to the transformation of the music school into a branch of the Lviv Higher Music Institute named after M. Lysenko ${ }^{15}$. Acquiring the

\footnotetext{
${ }_{12}^{12}$ Діло. Львів, 1905. Ч. 133.

13 Янович. Руська музична школа. Діло, 1902. Ч. 186.

14 Людкевич С. П. Дослідження, статті, рецензії, виступи : в 2-х томах / С. П. Людкевич / упорядкування, редакція, переклади, вступна стаття і примітки 3. Штундер. Львів : видавництво М. Коць; НАНУ, Інститут українознавства ім. І. Крип'якевича, 2000. 815 с. (Серія: Історія української музики, вип. 5; т. 2.)

15 Залеський О. Музичне життя Станислава. Альманах Станиславівської землі. Збірник матеріалів до історії Станиславова і Станиславівщини. Т. І. Нью-Йорк - Торонто - Мюнхен, 1985. С. 555.
} 
degree of philologist at the University of Lviv, he simultaneously studied musicology at the Department of Professor A. Khibinsky, and also attended lectures at the Higher Music Institute named after M. Lysenko, and later at the Polish Conservatory of the Galician Music Society, where he studied piano, flute, music theory and choral singing. Having become interested in music, O. Zaleski continued to improve his knowledge at the University of Vienna, studying with famous professors: the history of music - with I. Adler, musical aesthetics - with R. Wallashek. In addition, he attended the Kaiser's private music school, where he studied piano with W. Kaiser, harmony with D. Kaiser, and counterpoint and composition with A. Boscketti. Areas of Zaleski's musical interests were quite wide and included publishing, criticalanalytical, musicological and compositional activities. O. Zaleski's public and cultural-artistic activity was extremely active and had a significant influence on the development of culture and education in both Stanislaviv and Galicia.

Activities of the branch of the Higher Music Institute named after M. Lysenko were diverse and important, which primarily contributed to the formation and development of music education in the city and region of the first half of the twentieth century, by training qualified performing and teaching staff. The purpose of this educational institution was to provide students with a thorough, comprehensive music education, through the synthesis of a wide range of theoretical and practical disciplines ${ }^{16}$. The structure of the Stanislaviv's branch of the institute provided for division into 3 departments: solo and choral singing; playing the piano (harmonium); playing orchestral instruments. The branch created three levels (3 years each) of piano playing with a certain division into upper, middle and lower courses, which together amounted to 9 years. Piano performance has always been the basis of every music school. In the early 1930's, all specialties had a similar division into courses. At the same time, the following subjects were studied at the institute: music theory; a composition that combined harmony, counterpoint and composition; solo singing; choral singing with a broad consideration of church singing; history of music (Western European, Eastern European to modern times, oriental, Greek and church); piano playing; playing orchestral instruments: violin, viola, cello, double bass, flute, clarinet, trumpet and others. All subjects were divided into such groupes: main subjects of study (solo and choral singing, piano and orchestral instruments), i.e. major subjects; additional subjects (music theory, harmony, additional instrument - piano and music history); optional subjects "extracurricular", that included all scenic disciplines (recitation, facial expressions, scenic behavior, dance, basics of the Italian language).

Regular summary concerts (so called "popys") including the best students' performances contributed to the education of scenic poise, self-control,

\footnotetext{
${ }^{16}$ Повідомлення Вахнянина про діяльність культурно-освітніх товариств Галичини. ЦДІА України у Львові (Центральний державний історичний архів України у Львові). Ф. 818. оп. 1. спр. 20. 44 арк. 
professional skills, activity, which was one of a professional musician's educational method's components. The organization of choral, orchestral and chamber-instrumental groups played an important role in the process of training performance skills. A large number of posters with programs and lists of participants in the reporting concerts had been preserved. One of the first of such events, organized by the branch of the institute, was praised by the outstanding composer and musicologist Stanislav Lyudkevych, who noted the high level of violinists' training: 'all over in the violin training we have seen an excellent move of a fiddlestick, rhythmic solidity and clear tone, and among the second and fourth year students - even outstanding talents, very skillfully led to artistic achievements by the professor ${ }^{17}$.

Beginning with the 1925/26 academic year, the Higher Institute of Music organized collaborative concerts of the branch students in Lviv and major cities of the region. In particular, the collaborative concert of May 1937, which took place in Lviv, combined the performances of students of Stanislaviv, Kolomyia, Yavoriv,Ternopil and Stryj branches in its program. Students of the Stanislaviv's branch of the institute, including Yu. Tsybrivsky (class of S. Kryzhanivska), L. Trach, B. Zubal (class of D. Kolessa), had especially stood out, confirming the high professional level of the teaching staff, the effectiveness of the chosen teaching methods and the presence of gifted outstanding musicians among students ${ }^{18}$.

From the 1920s onwards, theme-based concerts became widespread in the musical life of Galicia. One of these artistic events took place in Stanislaviv (1926) and was dedicated exclusively to the work of German composer J.S. Bach. Its organizers were students of the institute branch. The concert program was not limited to piano compositions, but also combined vocal and violin works of the genius composer. This concert had a significant educational and artistic-educational value, as it allowed both the performers themselves and the general audience to touch the peaks of the Baroque musical art.

The evening of European dance music, which was dedicated to the works of F. Chopin, A. Dvorak, F. Kreisler, I. Brahms, A. Rubinstein and J. Strauss, left vivid impressions on the Stanislaviv audience. The event, organized by the branch of the Music Institute on June 1, 1935 in the hall of the Ukrainian Falcon included performances by soloists (piano, violin), as well as a piano duo and choir "Stanislavivsky Boyan".

Alongside with Western European music, Ukrainian music, which was part of the repertoire of soloists and creative groups, did not go unnoticed by teachers and students of the branch. The "Evening of Ukrainian Music", which was organized by the teaching staff of the branch and took place on

\footnotetext{
17 Людкевич С. Попис елєвів Музичного Інституту в Станіславові / Дослідження, статті, рецензії, виступи. Львів : Видавництво М. Коць, 2000. Т. 2. С. 473.

${ }^{18}$ Сімович Р. Попис учнів філії Музичного інституту ім. Лисенка. Назустріч. Львів, 1937. Ч. 11.
} 
May 16, 1936, was remembered by the performance of solo piano and vocal compositions. This creative evening became an important educational and training event, the content of which expanded the younger generation's understanding of the national culture, as well as contributed to the enrichment of the audience's artistic impressions.

An extraordinary event in the musical life of Stanislaviv was a concert of Scandinavian music, organized by the Music Society named after M. Lysenko and the men's choir Dumka, which took place in 1938. The trio of the Music Institute branch teachers consisting of R. Simovych (piano), I. Senkevych (violin) and I. Nedilsky (cello) was noted for the high level of performing skills, demonstrated active creative work of the teaching staff, aimed at improving their own professional level in music. Such events promoted the work of composers of different epochs and styles, as well as were important links in education and upbringing in the Higher Music Institute branch.

The activity of the Higher Music Institute branch highly raised the Ukrainian musical art in Stanislaviv. Both students and teachers of this educational institution were active participants of jubilee celebrations, concerts of creative organizations (Music Society named after M. Lysenko, Stanislavivsky Boyan, etc.), lectures, concerts, evenings of classical music. This became an important and effective factor that contributed to the acquaintance of the general public with musical works by talented artists and the awakening of the musical life of the city and the region. The Higher Music Institute in Stanislaviv became the center of Ukrainian musical art, which united the best forces of the Ukrainian musical intellectuals.

\section{Features of music education at the Conservatory of the Musicsociety named after Stanislaw Moniuszko}

Simultaneously with Ukrainian educational institutions in Stanislaviv there were Polish ones, among which the duration and efficiency of work was distinguished by the Conservatory named after S. Moniuszko (founded in 1879), which (in active cooperation with the Music Society named after S. Moniuszko) launched a wide range of musical and educational activities. For a long time, the conservatory remained the only educational institution in the city and the whole Carpathian region, which allowed it to master musical disciplines at a fairly high professional level. This was due to the presence of a highly qualified teaching staff, which included graduates of leading music universities of Europe ${ }^{19}$.

The active and fruitful activity of the Conservatory in Stanislaviv contributed to the rise of the musical culture of the city's polyethnic population. For the period from 1879 to 1939 a large constellation of

\footnotetext{
${ }^{19}$ Statut towarzystwa «Teatr im. Moniuszki w Stanisławowie. ДАІФО (Державний архів ІваноФранківської області). Stanisławów, 1879; 1905; 1928; 1933. 14; 16; 19; 33 ss. 
musicians was trained at the Conservatory of the Music Society named after S. Moniuszko, contributing greatly to the development of music education and upbringing by their work in educational institutions, orchestras, choirs and societies.

Throughout the time of the Conservatory's work it was being headed by several principals: at its early stage - by Lucian Kvitsinsky and Vladislav Antonevsky, later - by Marian Dorozhynsky (since 1925), Alfred Stadler (since 1927), Tadeusz Jarecki (since 1931), Maximilian Herr (with 1937) and Victor Gausman (since 1938).

The Conservatory's schooling year began in mid-September and lasted until the end of June. Both children and adults with the appropriate level of musical talent and compulsory school education were admitted to study. Term of study at the Conservatory of the Music Society named after S. Moniuszko (CMSM) depended on the specialty and changed in the process of the educational institution's development. It usually took from 8 to 12 years to obtain a diploma. It was a mandatory period during which the student had to master the program requirements. Most of the pupils combined music studies at the Conservatory with studies in secondary schools.

One of the forms of control and reporting were summary concerts (so called "popys") by Stanislaviv Conservatory students, which mostly took place on the last Sunday of the month and were held from three to nine times a year. Both soloists and chamber ensembles and orchestras took part in them. These performances were widely covered by the local press, in which reviewers gave a critical assessment of the Conservatory students' level of professional training and expressed their views on the prospects of this educational institution's development.

Additionally to summary concerts (so called "popys"), the Conservatory held large annual concerts twice a year. Involving students in performances on these events contributed to the formation of performance freedom and education of scenic poise at public events. At the end of each academic year, annual exams were held in front of a commission consisting of the principal, teachers and representatives of the MSM administration. Transitional annual exams were mandatory after each class.

To obtain their diplomas, students took final exams, which, in addition to the Conservatory's management and teachers, were attended by an inspector. In particular, the delegate of the Ministry of Education, Captain Boguslaw Sidorowicz, was a member of the examination commission from June 19-20, $1936^{20}$. Conservatory of the Music Society named after S. Moniuszko was issuing two types of diplomas: executive (diploma with honors) and pedagogical, permitting the graduates to teach others. Only a small number of

\footnotetext{
${ }^{20}$ Sprawozdanie z działalnosci wydziału Towarzystwa "Teatr im. Moniuszki", towarzystwo muzycznodramatyczne w Stanisławowie. Rok 1936/1937. Stanisławów, 1937. 31 s.
} 
students who reached the appropriate level of performance were allowed to take the final exams. The educational process was divided into certain stages. There were elementary, lower, middle and higher courses for all specialties. Only a small number of students, aspiring to work in music field continued their studies up to the senior year.

Archival documents confirm that in the first years of the school's work the performing specialties of piano, violin, cello, solo singing, and flute were opened. Subsequently, the professional departments expanded, classes of trumpet, bassoon, clarinet were added. The duration of study in different departments differed: piano - for 9 years, violin, cello - for 9 years, composition - for 7 years, solo singing - for 6 years and orchestral (wind) instruments - for 6 years $^{21}$. All specialties obligatory included studies of theoretical disciplines, incorporating the theory and history of music, harmony, counterpoint, musical forms, instrumentation, methods of educational singing and didactics. Additionally, a conducting course and a choir class were introduced into the training system ${ }^{22}$. Along with the major specialty, students could learn to play additional instruments. In particular, the piano was introduced for violinists and vocalists. The viola was additionally introduced in the violin class, students of which were obliged to participate in the Conservatory orchestra starting from the 2 nd grade of the lower course. Students of the piano and violin courses also had the opportunity to study in a chamber class ${ }^{23}$.

Involving students in the Music Society's choir or symphony orchestra was a common practice since the very beginning of this educational institution. Such a significant amount of planned work and the success of its implementation proved the high professional level of the Conservatory, which was very popular among the public of the city and the region. Most parents, not only from Stanislaviv but also from other cities in Galicia, sent their children to a Polish institution, as it had more qualified teachers, authorities' support and constant funding. The level of training of the Conservatory students allowed those wishing to continue their studies to enter the best music universities of Europe.

A distinctive feature of the Conservatory was the active concert and performance activities of its teaching staff, which served as a bright example for the younger generation of musicians and was one of the forms of educational process. Thus, the season of 1933/34 was marked by a series of concerts of chamber and instrumental music. The program of the first of them was dedicated to ancient and modern music, performed by Conservatory

\footnotetext{
21 Статистичні дані про стан консерваторії музичного товариства ім. С. Монюшка у місті Станислав. ЦДІА України у Львові (Центральний державний історичний архів України у Львові). Ф. 179. оп. 4. спр. 766. Арк. 1-6.

${ }_{22}$ Kurjer Stanislawowsky. Stanislawow, 1929. 30.06.

${ }^{23}$ Sprawozdanie z działalnosci wydziału Towarzystwa "Teatr im. Moniuszki", towarzystwo muzycznodramatyczne w Stanisławowie. Rok 1929/1930. Stanisławów, 1930. 33 s.
} 
professors Heinrich Gunsberg (piano) and Joseph Finkelstein (violin). At the concert they performed compositions of different eras, genres and stylistic trends. Works by J. F. Rameau, F. Couperin, J.S. Bach, K. Debussy, M. Ravel, S. Prokofiev, M. de Falla were performed, and their performance gathered a large number of classical music fans to the hall of the Theater named after S. Moniuszko and became one of the extraordinary events in the Stanislaviv's musical life ${ }^{24}$.

The second concert represented the Conservatory teachers string quartet, performing by the B major quartet of J.S. Bach. Listeners of this concert also had the opportunity to hear the original interpretation of the piano trio of op. 10 by the contemporary Polish composer and conductor G. Fitelberg. Along with the ensemble performances, the program included performances by soloists. Namely, Professor Jan Litynski impressed with the highly artistic and technical performance of piano works by Polish composers F. Chopin and K. Szymanowski. This talented pianist (a graduate of the Conservatory of Music Society named after S. Moniuszko) performed solo on various stages of Stanislaviv and the region and was recognized by a wide audience of music fans. The new teacher of the Conservatory, Halyna Myrchynska (cello), also performed at a high level. Her playing was impressive in its technics, bright timbre color and original interpretation of the performed works.

The next concert of the season combined solo and orchestral numbers in its program. Under the direction of Tadeusz Jarecki, the Conservatory's student orchestra performed GF Handel's Concerto grosso № 6, and Professor Heinrich Gunsberg impressed the audience with his refined and highly artistic interpretation of Mozart's concerto in E flat major for piano and orchestra.

The pedagogical and performing work of teachers had a positive effect on the level of Conservatory students' preparation, systematically involving them into concert activities. In addition to traditional summary concerts, there were reporting concerts, anniversary evenings, thematic concerts, evenings of chamber and symphonic music.

Three mornings and three evenings prepared by the Conservatory students became significant. Students of the brass department took an active part in these concerts, the students of the trumpet and bassoon class of Professor L. Korczyński (Leona Korczyńskiego) among them, were noted for their high level of preparation. Students of the chamber music class under the direction of Professor J. Finkelstein impressed the audience with their mastery of performing various genres. Such artistic events gave students the opportunity to demonstrate their professional growth in various forms of concert performances, which contributed to the intensification of the educational process.

\footnotetext{
${ }^{24}$ Sprawozdanie z działalnosci wydziału Towarzystwa “Teatr im. Moniuszki”, towarzystwo muzycznodramatyczne w Stanisławowie. Rok 1933/1934. Stanisławow, 1934. 29 s.
} 
In addition to participating in the Conservatory orchestral and choral groups, students have repeatedly performed solo concert programs. In particular, in the 1936/37 academic year, three alumni concerts took place, two of which were dedicated to cello music performed by Franciszeka Drahomireckiego (a student of Halyna Myrchynska). The next concert's program united the two departments. The first section featured piano works by Western European classical music, prepared by Jan Szwaczyński, and the second section featured the debut of singer Lucja Weintraub (coloratura soprano), a graduate of Ernie Alarmieri, and performed by Orni Hallerner ${ }^{25}$. Such events contributed to the creative formation of performers, directed their activities to the optimal artistic realization of the composer's idea in the stage and psychologically prepared for a solo career.

Another traditional Conservatory activity were "Fragments from operas" evenings, including performances by the students of the solo singing class E. Haller, as well as the student choir and orchestra. One of the active participants in these concerts was a Conservatory studen, the future opera star of Ukrainian origin Ira Malaniuk ${ }^{26}$. The programs of musical evenings combined selected scenes, orchestral, ensemble and solo performances from famous operas by composers of the past and present. Among them were fragments from the operas "Spiders" by R. Leoncavallo, "Rigoletto", "Masquerade Ball" by J. Verdi, "The Scary Yard", "Pebbles" by S. Monyushko, "Manon" by J. Massenet and others. These facts indicate the level of professional training and capabilities of the Conservatory teaching and student staff, who were able to perform not only fragments but also entire operas.

The professional skills of KMTM teachers allowed them to train worthy students who honorably represented this educational institution on the city and regional stages. The conservatory became a real "personnel source" for music and educational institutions of the region, its graduates worked in choirs, orchestras, seminaries and the Higher Institute of Music. Among them, V. Vyslotsky, who was a student of S. Krebs and led a class of stringed instruments, distinguished himself by his successful teaching activity at the Stanislavivka branch of the VMI.

Conservatory students could participate not only in its artistic groups, but also in orchestras and choirs of other educational institutions. Such events gave students of the Stanislaviv Conservatory the opportunity to objectively assess their level of performance in comparison with other musicians. At the same time, teachers got acquainted with new methods and areas of music pedagogy. Performing the concert programs at Polish and Ukrainian high

\footnotetext{
${ }^{25}$ Sprawozdanie z działalnosci wydziału Towarzystwa "Teatr im. Moniuszki”, towarzystwo muzycznodramatyczne w Stanisławowie. Rok 1936/1937. Stanisławów, 1937. 31 s.

${ }^{26}$ Маланюк І. Голос серця : автобіографія співачки / пер. 3 нім. А. Ільницької; комент., довід. відділ Б. Котюк. Львів : Collegium musicum Львів. т-ва Р. Вагнера, 2001. 306 с. : іл. 
schools, KMTM students carried out significant educational work, thus contributing to the rise of musical culture of the city and region. For example, in June 1938, students from the Urshulyan Sisters Gymnasium and the Conservatory Students' Orchestra performed Our Life, a play with music by Wiktora Hausman and conducted by the author himself $f^{27}$.

A separate page of the Conservatory's activity is its close cooperation with the S. Monyushko Music Society. Teachers combined pedagogical work with participation in the affairs of the society, conducting active concert activities. The heads of the music school were members of the Artistic Commission, where they headed the music section and acted as conductors. In three concerts for secondary schools, taking place in 1936-37, the Society orchestra was conducted by the director of the Conservatory T. Yaretsky and professor of violin and chamber class J. Finkelstein.

The intensive participation of teachers and students in the concert life of Stanislaviv and other cities brought a fresh stream to the wide flow of artistic processes in Precarpathia, enriching it with concerts of chamber, instrumental and choral music. "Fragments from operas" evenings including performances by solo singing class students, as well as a student's choir and an orchestra became traditional. The programs of these evenings combined individual scenes, orchestral, ensemble and solo performances from famous operas by composers of the past and present.

The artistic progress was greatly facilitated by the opening in 1885 of the Kolomyia branch of the MTM and its music school, which in 1928 was reorganized into the "S. Monyushko Music Conservatory in Stanislaviv, Kolomyia branch". Along with other music schools that operated in the late nineteenth - early twentieth century, the Conservatory had been creating the foundation on which a bright palette of Galician musical culture unfolded itself.

\section{CONCLUSIONS}

The process of Stanislaviv cultural and educational life development in the late XIX - first third of the XX century has its own characteristics and at the same time is an integral part of the artistic processes that took place in the western lands at that time. During this period, a significant rise in this area becomes obvious, due to the democratization of socio-political life, openness to mutual influences and interpenetration of different peoples' cultures. Increasing the intensity of the music education development contributed to the intensification of cultural and artistic life, resulting in an increase of the spirituality level of the general population of the Stanislaviv city and Western Ukraine in general. The system of music education reflected, on the one hand,

\footnotetext{
${ }^{27}$ Sprawozdanie z działalnosci wydziału Towarzystwa "Teatr im. Moniuszki", towarzystwo muzycznodramatyczne w Stanisławowie. Rok 1937/1938. Stanisławów, 1937. S. 16.
} 
the main principles of the state general education system with differentiation on social grounds, on the other hand, the state of music culture, which organically combined interpenetrating streams of spiritual, secular and folk music cultures.

The system of music education in secondary schools provided for the study of the subject of music and singing as one of the main, and in teachers' seminaries the violin was introduced as a compulsory lesson. Musical education of schoolchildren took place not only within the educational process, but also was provided by extracurricular student organizations, where "Scientific circles" gained paramount importance. This allowed a wide student community to join the art of music and thus expand their worldview.

During a certain period in Stanislaviv there were specialized educational institutions of different types and levels, which trained professionals for performing and pedagogical activities. These included schools of music societies and higher educational institutions. In particular, in the first two decades of the twentieth century the music school opened by Stanislavivsky Boyan (growing later into a branch of the Lysenko Higher Music Institute) became active, becoming the Western Ukrainian creative intelligentsia's highest achievement in the formation and development of national music education. Along with the Ukrainian ones in Stanislaviv, there were Polish educational institutions working fruitfully, Conservatory named after S. Monyushko among them. In active cooperation with the S. Monyushko Music Society it launched a wide range of musical and educational activities. By the organizational form of the educational process these institutions were close to the Western European conservatories, as evidenced by the presence of highly qualified teachers and well-balanced curricula. They were distinguished by their multifaceted activities, including the qualified musical personnel training for performing and pedagogical work, concert, educational and propaganda, educational spheres.

A large number of leading musicians, whose creative activities contributed to the progress of Ukrainian art in Western Ukraine, came out of the these musical institutions' walls. These educational institutions have become the main centers for training professional musicians in Stanislaviv and its region.

Increasing the intensity of the music education development contributed to the intensification of cultural and artistic life, resulting an increase in the cultural level of the general population of Stanislaviv and Western lands. The system of music education reflected, on the one hand, the main principles of the state general education system of the time, and on the other hand, the state of music culture. 


\section{SUMMARY}

The article presents the main stages of formation and development of cultural and educational processes in Stanislaviv (now Ivano-Frankivsk), typical for the western Ukrainian lands of the last quarter of the XIX - first third of the XX centuries. It was found that music education functioned in cultural and educational institutions of different levels and profiles and was implemented in certain forms. These included: a) lower, i. e. unorganized (home, private); b) cultural and educational organizations (music and public education societies); c) organized forms of music education (specialized music schools, divided into lower, middle and higher levels); d) general educational institutions of different level and profile (schools, gymnasiums, vocational schools, seminaries, scholarships, etc.). The activities of a number of Ukrainian, Polish, Jewish public educational and artistic societies, including Prosvita, Ridna Shkola, Ruska Besida, Soyuz Ukrainok, Kamenyari, Gaskala, Stanislavivsky Boyan, and Stanislavivsky Boyan, S. Monyushko Society and others, proved to be active in the field of music and art education were studied. The peculiarities of educational processes in general and specialized educational institutions of Stanislaviv, where music and art education was an important part of activity, are characterized. The work of the Higher Music Institute named after M. Lysenko branch in Stanislavov is publisiced, being diverse, invaluably important, and primarily contributing to the formation and development of music education in the city and region in the first half of the twentieth century. Thanks to the activity of the teaching and student staff of this educational institution, the concert life of the city was enriched by high professional level artists' performances. The Higher Music Institute in Stanislaviv became the center of Ukrainian musical art, uniting the best forces of the Ukrainian musical intelligentsia. The role of the S. Moniuszko Music Society Conservatory in the western Ukrainian lands was also noted.

\section{REFERENCES}

1. Білавич Г., Савчук Б. Товариство «Рідна школа» (1881-1939 рр.). Івано-Франківськ : Лілея - НВ, 1999. 205 с.

2. Діло. Львів, 1889. Ч. 207.

3. Діло. Львів, 1905. Ч. 133.

4. Загайкевич М. Музичне життя Західної України другої половини ХІХ століття. Київ : АН УРСР, 1960. 191 с.

5. Залеський О. Музичне життя Станислава. Альманах Станиславівської землі. Збірник матеріалів до історії Станиславова $i$ Станиславівщини. Т. І. Нью-Йорк - Торонто - Мюнхен, 1985. С. 555. 
6. Звідомлення управи приватної дівочої гімназії кружка «Рідної школи» в Станиславові за шкільні роки 1920/21 - 1926/27. ДАІФО (Державний архів Івано-Франківської області). Станиславів, 1927.30 с.

7. Звіт дирекції державної гімназії з руською викладною мовою у Станиславові за шкільний 1936/37. Станиславів, 1937. 47 с.

8. Звіт про проведення режисерських курсів керівників сільських аматорських гуртків. Відношення про проведення Свята Молоді. ДАІФО (Державний архів Івано-Франківської області). Ф. 378. оп. 1. спр. 46. 13 арк.

9. Куцій М. Наука сольфежа основана на мельодіях 3 текстом : Підручник для молодіжи. Перша частина. Станиславів, 1927. 54 с.

10. Людкевич С. П. Дослідження, статті, рецензії, виступи : в 2-х томах / С.П. Людкевич / упорядкування, редакція, переклади, вступна стаття і примітки 3. Штундер. Львів : видавництво М. Коць; НАНУ, Інститут українознавства ім. І. Крип'якевича, 2000. 815 с. (Серія: Історія української музики, вип. 5; т. 2.).

11. Маланюк I. Голос серця : автобіографія співачки / пер. 3 нім. А. Ільницької; комент., довід. відділ Б. Котюк. Львів : Collegium musicum Львів. т-ва Р. Вагнера, 2001. 306 с. : іл.

12. Повідомлення Вахнянина про діяльність культурно-освітніх товариств Галичини. ЦДІА України у Львові (Центральний державний історичний архів України у Львові). Ф. 818. оп. 1. спр. 20. 44 арк.

13. Протоколи, анкети конкурсу драматичних гуртків читалень «Просвіти» Станиславівського повіту. ДАІФО (Державний архів ІваноФранківської області). Ф. 378. оп. 1. спр. 43. Арк. 1-7.

14. Сімович Р. Попис учнів філії Музичного інституту ім. Лисенка. Назустріч. Львів, 1937. Ч. 11.

15. Станіславська приватна жіноча учительська семінарія Сестер Василіянок. ДАІФО (Державний архів Івано-Франківської області). Ф. 548. оп. 1, спр. 5.49 арк.

16. Станіславська приватна чоловіча учительська семінарія Українського Педагогічного товариства. ДАІФО (Державний архів Івано-Франківської області). Ф. 303. оп.1. спр.1. 91 арк.

17. Статистичні дані про стан консерваторії музичного товариства ім. С. Монюшка у місті Станислав. ЦДІА Украйни у Львові (Центральний державний історичний архів Украӥни у Львові). Ф. 179. оп. 4. спр. 766. Арк. 1-6.

18. Янович. Руська музична школа. Діло, 1902. Ч. 186.

19. Ясінчук Л. 50 літ Рідної школи 1881-1931. Львів : Видавництво «Діло». С. 14-28.

20. Kurjer Stanislawowsky. Stanislawow, 1929. 30.06. 
21. Statut towarzystwa "Teatr im. Moniuszki" w Stanisławowie. ДАІФO (Державний архів Івано-Франківської області). Stanisławów, 1879; 1905; $1928 ; 1933.14 ; 16 ; 19 ; 33$ ss.

22. Sprawozdanie z działalnosci wydziału Towarzystwa "Teatr im. Moniuszki”, towarzystwo muzyczno-dramatyczne w Stanisławowie. Rok 1929/1930. Stanisławów, 1930. 33 s.

23. Sprawozdanie z działalnosci wydziału Towarzystwa "Teatr im. Moniuszki", towarzystwo muzyczno-dramatyczne w Stanisławowie. Rok 1936/1937. Stanisławów, 1937. $31 \mathrm{~s}$.

24. Sprawozdanie z działalnosci wydziału Towarzystwa "Teatr im. Moniuszki", towarzystwo muzyczno-dramatyczne w Stanisławowie. Rok 1933/1934. Stanisławow, 1934. 29 s.

\section{Information about author:} Romaniuk L. B., Candidate of Art Studies, Associate Professor, Associate Professor at the Department of Music Ukrainian Studies and Folk Instrumental Art Vasyl Stefanyk Precarpathian National University 57, Shevchenko str., Ivano-Frankivsk, 76018, Ukraine 